\title{
PERSPECTIVE COOPERATION OF UZBEKISTAN WITH ISLAMIC EDUCATIONAL, SCIENTIFIC AND CULTURAL ORGANIZATION (ICESCO)
}

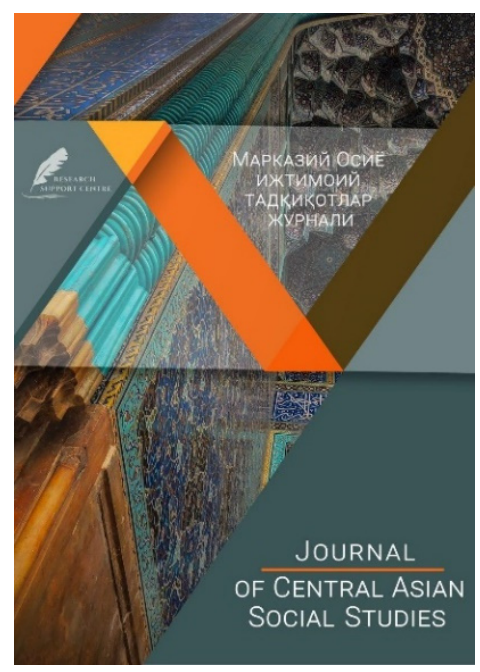

\author{
Shakhzod Timurovich Khatamov \\ Trainee researcher, \\ International Islamic Academy of Uzbekistan \\ E-mail: tiushakhzod@mail.ru
}

Abstract: This article provides information the history of development of Uzbekistan's relations with ICESCO, Uzbekistan, as a full member of the OIC, plays an important role in its huge social, spiritual and economic potential. A number of countries around the world, especially in the foreign policy of the Republic of Uzbekistan, Central Asia, international relations, including cooperation with the world's leading countries and international organizations, issues of bilateral and multilateral cooperation in the priority areas of sustainable development, regional integration processes research is underway.

Key words: ICESCO, Islamic solidarity, Uzbekistan's Development Strategy for 2017-2021, Ninth Conference of Ministers of Culture of the Member States of the Organization of Islamic Cooperation (OIC), 43rd session of the Council of Foreign Ministers of the Organization of Islamic Cooperation, Capital of Islamic Culture, scientific heritage, tolerance.

\section{O'ZBEKISTONNING ISLOM TA'LIMI, ILMIY VA MADANIY TASHKILOTI (ICESCO) BILAN ISTIQBOLLI HAMKORLIGI}

Annotatsiya: Mazkur maqolada O'zbekistonning ICESCO bilan munosabatlar rivojlanish tarixi haqida ma'lumot berilgan. O'zbekiston IHTning to'laqonli a'zosi sifatida o'zining ulkan ijtimoiy, ma'naviy va iqtisodiy salohiyati bilan muhim o'rin tutadi. Jahonning bir qator mamlakatlarida Markaziy Osiyo, xususan, O’zbekiston Respublikasining tashqi siyosiy faoliyati, xalqaro munosabatlari, jumladan, dunyoning yetakchi mamlakatlari va xalqaro tashkilotlari bilan hamkorlik aloqalari, barqaror taraqqiyot masalalari, ikki va ko'ptomonlama hamkorlikning ustuvor yo'nalishlari, mintaqaviy integratsion jarayonlarni tahlil qilish yuzasidan ilmiy izlanishlar olib borilmoqda.

Kalit so'zlar: ICESCO, Islom birdamligi, O'zbekistonning 2017-2021 yillarda rivojlanish strategiyasi, Islom hamkorlik tashkilotiga (IHT) a'zo davlatlar madaniyat vazirlarining to'qqizinchi konferensiyasi, Islom hamkorlik tashkiloti tashqi ishlar vazirlari kengashining 43-sessiyasi, Islom madaniyati poytaxt, ilmiy meros, bag'rikenglik. 


\section{ПЕРСПЕКТИВНОЕ СОТРУДНИЧЕСТВО УЗБЕКИСТАНА С ИСЛАМСКОЙ ОБРАЗОВАТЕЛЬНОЙ, НАУЧНОЙ И КУЛЬТУРНОЙ ОРГАНИЗАЦИЕЙ (ICЕSСО)}

Аннотация: В статье представлена история развития отношений Узбекистана с ICESCO, Узбекистан, как полноправный член ОИК, играет важную роль в его огромном социальном, духовном и экономическом потенциале. Ряд стран мира, особенно во внешней политике Республики Узбекистан, Центральной Азии, международных отношениях, включая сотрудничество с ведущими странами мира и международными организациями, вопросы двустороннего и многостороннего сотрудничества по приоритетным направлениям устойчивого развития, Исследования региональных интеграционных процессов продолжаются.

Ключевые слова: ICESCO, Исламская солидарность, Стратегия развития Узбекистана на 2017-2021 годы, Девятая конференция министров культуры государств-членов Организации исламского сотрудничества (ОИС), 43-я сессия Совета министров иностранных дел Организации исламского сотрудничества, Столица исламской культуры, научное наследие, толерантность.

\section{Introduction}

Islamic World Educational, Scientific and Cultural Organization (ICESCO) is a specialized organization that operates under the aegis of the Organization of Islamic Cooperation (OIC), and is concerned with fields of education, science, culture and communication in Islamic countries in order to support and strengthen relations among Member States. ICESCO was founded by the Organization of Islamic Cooperation (OIC) in May $1979^{1}$. With 54 member states, the working languages of ICESCO are Arabic, English and French.

One of the most striking examples of attempts by intergovernmental organizations to influence regional and world political processes is the Organization of the Islamic Conference (OIC), created in 1969 on the initiative of Saudi Arabia and uniting 57 Muslim states, including some CIS (Commonwealth of Independent States) countries - Azerbaijan, Kazakhstan, and Kyrgyzstan, Tajikistan, Turkmenistan,

\footnotetext{
1 "History | Islamic Educational, Scientific and Cultural Organization - ISESCO -". www.isesco.org.ma. Retrieved 2018-02-24.

${ }^{2}$ CM. «bolstering Islamic solidarity among member states», «supporting cooperation among member states in economic, social...fields», «supplying the strength of all Islamic countries to preserve the dignity,
}

Uzbekistan. We also emphasize that the OIC is the largest Muslim organization which is declared objectives are such as, for example, "promoting the strengthening of Islamic solidarity", promoting cooperation and understanding between Member States and other countries. ${ }^{2}$ International organizations are one of the best means of multilateral cooperation, within which states solve various complex issues of international relations. As is known, Uzbekistan is widely known to the world community by those cultural and intellectual traditional values, which in many respects were shaped under the influence of Islam.

\section{Results and Discussion}

The phenomenon of the modern stage of social development is the revival and wide spread of Islamic values. Similar trends are taking place in the countries of Central Asia, which are characterized by a long history of Islamic civilization. The acquisition of state sovereignty was the beginning of a new stage in the revival of Muslim values in Central

independence and national rights» $и$ «creation the atmosphere that bolsters cooperation and understanding among member countries... and other countries»// File of Islamic Summit Conferences and Islamic Conferences of Foreign Ministers. Saudi Press Agency, 1989. P. 20. 
Asian countries, and in particular, in Uzbekistan. As is known, Uzbekistan is widely known to the world community by those cultural and intellectual traditional values, which in many respects were shaped under the influence of Islam. ${ }^{3}$

In these days, the Republic of Uzbekistan has established diplomatic relations with more than 130 countries of the world. In Tashkent, 45 embassies of foreign countries, 8 honorary consuls, 19 representative offices of international organizations, 18 representative offices of international intergovernmental and governmental organizations of foreign countries, and a trade mission with diplomatic status carry out their activities. The main goal of the foreign policy of the Republic of Uzbekistan is to strengthen the independence and sovereignty of the state, strengthen its place and role in the international arena, create a belt of security and stability around the country, actively promote the republic's foreign economic interests.

In foreign countries and with international organizations, there are 47 diplomatic and consular missions of the Republic of Uzbekistan. Uzbekistan is a member of over 100 international organizations and is developing interaction with various structures of multilateral cooperation. ${ }^{4}$ One of them is the organization of Islamic cooperation. The Organization of Islamic Cooperation - the international organization of Islamic countries until 2011 was called the Organization of the Islamic Conference (OIC). It was founded on September 25, 1969 at a conference of heads of Muslim states in Rabat with the aim of ensuring Islamic solidarity in the social, economic and political spheres, the struggle against colonialism, neo-colonialism and racism and the support of the Palestine Liberation Organization. The headquarters of

3 http://shosh.uz/nozimjon-dalibaev-vozrojdenieislamskoy-tsivilizatsii-v-uzbekistane-uroki-proshlogi-i nastoyashhego/ the organization is located in Jeddah (Saudi Arabia).

There are a number of organizations in the OIC. The Islamic Development Bank, the Jerusalem Fund, the Islamic Chamber of Commerce, the Organization of Islamic Capital, the Organization for Islamic Cooperation, and the Islamic Educational, Scientific and Cultural Organization. Their activities are coordinated by the General Secretariat.

The current OSCE system was adopted at a meeting in Dakar on 13-14 March 2008. The main goals and objectives of the organization are as follows:

- Harmonization of friendship and solidarity among Member States;

- Solving the problems arising in the Islamic world;

- Respect for domestic law of States;

- Human rights protection;

- Assisting Member States in their economic development; Islam;

- Removing misconceptions about

- Conducting scientific research with institutions in different countries.

The Organization of Islamic Cooperation is an officially recognized international Muslim organization and the largest organization in the world. Nowadays. 57 member states are members.

At the beginning of its establishment 25 members were members. The main goals of the organization are:

1) Establishing mutual cooperation between Muslim countries;

2) Organization of international activities on the basis of cooperation; 
3) Facilitating accession of the member countries to the number of developing countries.

The body overseeing the organization is:

- royal groups;

- Heads of State;

- members of the government;

- Foreign Ministers.

Uzbekistan has been a member of the OIC since 1996. Our Republic actively participates in all organizational conferences, and contributes to its worthy contribution.

The Organization of Islamic Cooperation is the main organization of Muslim countries in the world, and until 2011 was called the Organization of Islamic Conference. The Organization of Islamic Cooperation was adopted on 25 September 1969 in a conference organized by the Muslim Countries Conference in Robot, the main purpose of which is to consolidate Muslim countries in political and economic spheres. The following countries have observer status: Bosnia and Herzegovina, Central African Republic, Russian Federation and Philippine.

On June 28, 2011, by the decision of the 38th session of the Council of Foreign Ministers (OIC Ministerial Council) held in Astana, the Organization of the Islamic Conference was renamed the Organization of Islamic Cooperation (OIC). ${ }^{5}$ The Organization of Islamic Cooperation is the largest and most influential official governmental Muslim international organization. Currently unites 57 countries with a population of about 1.5 billion people. Initially, it consisted of 25 states of Asia and Africa and the Palestine Liberation Organization. The objectives of the creation of the OIC: cooperation between Muslim states, joint participation in activities in the

5 https://mfa.uz/ru/cooperation/ материалы 38-й сессии Совета министров иностранных дел (СМИД) ОИС. 28 июня 2011 г international arena, the achievement of stable development of the participating countries.

The Republic of Uzbekistan was admitted to the Organization of Islamic Cooperation (OIC) as an observer at an extraordinary meeting of the foreign ministers of the member states in New York in October 1995. Uzbekistan became a full member of the Organization on October 2, 1996. Since 2003 Uzbekistan is a member of a specialized institution of the OIC - Islamic Development Bank. The Republic signed a new OIC Charter on December 14, 2015. In April 2016 The statute was ratified by the Senate of the Oliy Majlis of the Republic of Uzbekistan.

The official delegation of Uzbekistan led by the Prime Minister took part in the work of the 3rd extraordinary summit of the OIC in Mecca (December 2005). The convening of this forum was dictated by the need to develop a new organization strategy aimed at consolidating Islamic states in the light of the emerging global geopolitical situation, as well as the transformation of the OIC into an effective institution capable of withstanding contemporary challenges and threats.

During the event, the Uzbek side made a proposal to develop a common position of the OIC member countries in international organizations, which was supported by the majority of the Muslim world and was subsequently included as a separate expanded paragraph in the appropriate section of the 10year Organization's program. Along with this document, the Meccan Declaration and the final Communiqué were adopted at the end of the forum, reflecting the desire of Islamic states to strengthen unity, develop a common position on new challenges and threats, and the need to promote the ideas of tolerant and enlightened Islam.

An important area in the activities of the Organization of Islamic Cooperation is the legal regulation of economic relations between member countries, as well as between them 
and other states - not members of this organization. Thanks to effective legal regulation within the framework of the OIC in the economic sphere, economic relations between the participating States are developing at an accelerated pace. It should be noted that within the framework of the Organization of Islamic Cooperation in the economic sphere, cooperation is developing successfully, rather than cooperation in the political sphere.

Highly appreciating the enormous attention paid by the Leadership of the Republic of Uzbekistan to preservation and enhancement of historical scientific and cultural-spiritual heritage, as well as the true values of Islam, such as aspiration for peaceful and tranquil life, tolerance in interethnic and interreligious relations, sense of mutual respect and accord, as well as development and improvement of education system, upbringing of the younger generation in the spirit of mastering the universal and Islamic values and peaks of modern science, reaffirming the full commitment to the goals and principles of the OIC in interests of Member States and support for peace, stability, sustainable socioeconomic development, advancement of science, education and enlightenment in the OIC countries in the framework of Islamic solidarity.

A confirmation of the special role of Uzbekistan in the history of Islamic civilization, in particular its capital, is that the International Islamic Organization for Education, Science and Culture (ICESCO), which is one of the structures of the Organization of the Islamic Conference, declared Tashkent "The Capital of Islamic Culture in 2007." This event aroused great interest in the republic itself and abroad. In this regard, a one-year marathon of scientific and practical, cultural and spiritual and educational events began in the republic, dedicated to this significant event. In choosing Tashkent's candidacy, ICESCO took into account, above all, the policy of the republic's leadership aimed at reviving the cultural and spiritual values of the Uzbek people, as well as the measures taken by the Government of Uzbekistan to protect and preserve the monuments of Islamic civilization. This ICESCO choice is also explained by the fact that the rich history and culture of one of the most ancient cities of Asia - Tashkent, the capital of Uzbekistan - occupy a special place in the history of world civilization.

Uzbekistan has acquired big authority in the Islamic world, with the attainment of independence people's life in Uzbekistan has changed dramatically. The country has become ever more beautiful, the protection of religious convictions of the citizens has been enhanced; they rehabilitated and restored sanctuaries, mausoleums, tombs and burial-vaults of prominent representatives of the Muslim world. ${ }^{6}$

The following are also among the objectives of ICESCO: to publicize the correct image of Islam and Islamic culture, promote dialogue among civilizations, cultures and religions, and work towards spreading the values of justice and peace along with the principles of freedom and human rights, in accordance with the Islamic civilizational perspective; to encourage cultural interaction and to support the aspects of cultural diversity in the Member States, while preserving the cultural identity and protecting the independence of thought; to consolidate complementarity and coordination among the specialized institutions of the Organization of Islamic Cooperation in the fields of education, science, culture and communication and among the Member States of ICESCO, and promote cooperation and partnership with the similar governmental and non-governmental institutions sharing the same interest, inside and outside the Member States and others. In accordance with the Article 6 of the Charter of the Islamic Educational, Scientific and Cultural Organization, every full Member State of the Organization of the Islamic Conference shall become a member of ICESCO upon signing officially the Charter,

\footnotetext{
6 www.mfa.uz
} 
and after it has completed the membership legal and legislative formalities and informed - in writing - the General Directorate of ICESCO.

Undoubtedly, ratification of the Charter by Uzbekistan opens wide opportunities for further development of international cooperation in the field of education, science and culture. This document has become one more legal basis for broad propaganda of Uzbekistan's achievements in cultural and humanitarian spheres.

Cooperation in Central Asia, in particular with foreign policy of the Republic of Uzbekistan, international relations, including with leading countries and international organizations, scientific research on sustainable development, priorities of bilateral and multilateral cooperation, and analysis of regional integration processes in a number of countries around the world. ${ }^{7}$

One of the main and priority tasks of foreign policy activity is the effective implementation of the Action Strategy in the five priority areas of development of the Republic of Uzbekistan in 2017-2021. To achieve this goal, the republic's foreign policy department has the following tasks:

- strengthening the independence and sovereignty of the state, further strengthening the place and role of the country as a full subject of international relations, joining developed democratic states, creating a belt of security, stability and good neighborliness around Uzbekistan 8 ;

It is important to note that a new powerful impetus was given after the arrival of the President of Uzbekistan Shavkat Mirziyoyev to power to ensure social stability, preserve the true essence and content of the holy religion of Islam, preserve and study the

\footnotetext{
7 Рахимов M. Современная история взаимоотношений Узбекистана и стран Центральной Азии с ведущими государствами мира.

- Ташкент: Адабиёт учқунлари, 2016. - 223 с.

${ }^{8}$ http://www.lex.uz/ru/docs/3107042
}

richest religious and spiritual heritage of great ancestors.

The Minister of Foreign Affairs of the Republic of Uzbekistan, $\mathrm{Mr}$ Abdulaziz Kamilov, handed the document on the accession of his country to the Islamic Educational, Scientific and Cultural Organization (ICESCO) to the Director General, Dr Abdulaziz Othman Altwaijri, during an official ceremony held this morning at the Ministry in Tashkent.

Therefore, the Republic of Uzbekistan becomes the $54^{\text {th }}$ Member State of ICESCO ${ }^{9}$.

The Charter of ICESCO was signed by the Republic of Uzbekistan on August 26, 2017. It consists of a preamble and 22 articles. In accordance with the Article 4, the objectives of ICESCO include the following: to strengthen, promote and consolidate cooperation among the Member States and consolidate it in the fields of education, science, culture and communication, as well as to develop and upgrade these fields, within the framework of the civilizational reference of the Islamic world and in the light of the human Islamic values and ideals. To consolidate understanding among peoples inside and outside the Member States and contribute to the achievement of world peace and security through various means, particularly through education, science, culture and communication $^{10}$.

The ratification of the Charter of the ICESCO will contribute to further development of international cooperation in education, science and culture and will additionally allow widely promoting achievements of Uzbekistan in the cultural and humanitarian spheres. The Tashkent Islamic University will organize work of the Special Chair of the ICESCO after the entry of the Charter into force.

\footnotetext{
9 https://www.ICESCO.org.ma/blog/2017/08/30/republic -of-uzbekistan-accedes-to-ICESCO-2/

10 http://uza.uz/en/society/huge-role-of-uzbekistan-indevelopment-of-islamic-culture-04-04-2018
} 
At the end of the session the participants adopted the Tashkent Declaration of the 43rd session of the Council of Foreign Ministers of the Organization of Islamic Cooperation. The Declaration emphasizes that the leadership of the Republic of Uzbekistan is committed to preserving and increasing its historical, scientific and cultural heritage, as well as the development and perfection of the educational system, such as tolerance in interethnic and interreligious relations, mutual respect and harmony, attaches great importance to the upbringing of the younger generation in the spirit of the acquisition of universal values and the passion for the achievement of the highest peaks of modern science was highly appreciated.

Opening of the department is an invaluable scientific heritage of the historical and scientific heritage of the past, bringing to future generations, deep understanding of the scientific heritage of our scientists and thinkers, their role in the history of modern culture, an incomparable scientific heritage of ideas of tolerance, peace and enlightenment, modern science and progress the importance of their discoveries and their intention to study and popularize their needs.

Understanding between the IIAU and the ICESCO on the establishment of ICESCO for the Study of Islamic Civilization (ICESCO of the Islamic Educational, Scientific and Cultural Organization and the IIAU under the Cabinet of Ministers of the Republic of Uzbekistan on the establishment of the ICESCO Chair for the Study of Islamic Civilizations Memorandum of Understanding, Rabot, 24.05.2017). On the basis of the Memorandum, the Decision of the TIU Decree No. 10 (30.05.2017) and the order of the Rector of the TIU on the establishment of the Islamic Educational Organization for Islamic Educational and Scientific Organization (ICESCO) in the Islamic University of Tashkent (01-278, 16.06. 2017 y.).

Currently, ICESCO has 18 ICESCO departments around the world. Including:

In non-ICESCO member states:
- Rotterdam University ICESCO Chair - The Kingdom of the Netherlands;

- ICESCO chair (Avicenna Humanitarian Institute, Lille, France); Training of specialists in the field of justification and communication in Islam;

- ICESCO chair / FUIW (Russian Islamic University, Kazan, Tatarstan)

- ICESCO Chair of Arabic Language and Islamic Culture (Moscow State Pedagogical University, Russia);

- ICESCO chair of the Caribbean dialect and Latin American communication (Buenos Aires, Argentina);

- ICESCO Department of International Solidarity and Cultural Diversity (Granada University, Spain);

Member States:

- Baku State University, Faculty of Oriental Studies ICESCO - Azerbaijan;

- Cairo University ICESCO Chair Egyptian Arab Republic;

- Umm al-Qura ICESCO Chair, Mecca - Kingdom of Saudi Arabia;

- ICESCO Chair by Koran inscription / FUIW, Niger Islamic University;

- ICESCO Chair of Cultural Diversity Uganda Islamic University;

- ICESCO Chair / African International University, Sudan Republic;

- ICESCO / UNESCO Chair for Women in African Region (Science and Technology Sudan University, Republic of Sudan);

- ICESCO / UNESCO Chair for Women in Asian Region (Lahore University, Pakistan);

-ICESCO Chair of Islamic Thought named after Prof. Abdulhodi Butolib (University named after Sidi Muhammad ibn Abdullah, Kingdom of Morocco, Morocco);

- ICESCO Chair of World Culture and Dialogue (Cairo University, Egypt); 
- ICESCO Chair of Science and Innovations, Women's Position (Comoros University, Comoros Islands Union);

- ICESCO Chair of Cultural Alliance (Qatar University, State of Qatar).

The department is called "ICESCO chair of the study of Islamic civilizations" "ICESCO Chair for the study of Islamic civilization", "CRYY الإيسيسكو لدراسات الحضارة

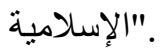

The special department is organized to study the history of education, science and culture in the Muslim world, as well as to study their current state of affairs and to teach them special courses for students.

According to the Declaration of the 43rd Session of the OIC Council for Foreign Affairs, the ICESCO Department is an educational, peaceful and tolerant Islamic religion. It also promotes an international aspect of the multifarious religious and spiritual heritage of our great ancestors that contributes not only to the Islamic culture, but also to the universal civilization.

The Islamic Educational, Scientific and Cultural Organization (ICESCO) is a specialized institution of the Organization of Islamic Cooperation (OIC) in the fields of Education, Science and Culture. It aims to strengthen, promote and consolidate cooperation among Member States in the fields of education, science, culture and communication, as well as develop and upgrade these fields, within the framework of the civilizational reference of the Islamic world and in the light of human Islamic values and ideals.

Uzbekistan has acquired big authority in the Islamic world, with the attainment of independence people's life in Uzbekistan has changed dramatically. The country has become ever more beautiful, the protection of religious convictions of the citizens has been enhanced; they rehabilitated and restored sanctuaries, mausoleums, tombs and burial-vaults of prominent representatives of the Muslim world.
The ratification of the Charter of the ICESCO will contribute to further development of international cooperation in education, science and culture and will additionally allow widely promoting achievements of Uzbekistan in the cultural and humanitarian spheres. The Tashkent Islamic University will organize work of the Special Chair of the ICESCO after the entry of the Charter into force.

The Islamic Educational, Scientific and Cultural Organization (ICESCO) is a specialized institution of the Organization of Islamic Cooperation (OIC) in the fields of Education, Science and Culture. It aims to strengthen, promote and consolidate cooperation among Member States in the fields of education, science, culture and communication, as well as develop and upgrade these fields, within the framework of the civilizational reference of the Islamic world and in the light of human Islamic values and ideals.

After the independence of Uzbekistan, a new period in the development of the spirituality of the Uzbek people. Attitude towards religion has changed radically. Today, the people of Uzbekistan are on the path to reviving national spiritual values, building a state with a great future.

In many cultures, the concept of "tolerance" is a synonym for "tolerance": Latin - tolerantia; English - tolerance; German Toleranz; French - tolérance.

Tolerance is a quality that must be present in every person. If a person has tolerance, then he is a noble person. This person has a high culture, he is humane.

Everyone has the right to freedom of thought, conscience and religion; this right includes freedom to change his religion or belief, and freedom, either alone or in community with others and in public or 
private, to manifest his religion or belief in teaching, practice, worship and observance ${ }^{11}$.

Believers of Uzbekistan freely celebrate all religious holidays. So, more and larger scale marked Eid al-Fitr and RamadanHait, Easter, Christmas, Passover, Purim, Hanukkah and other religious holidays.

Each country has a scientific and spiritual heritage of great thinker's reforms in the direction of deep study and promotion of the younger generation in the spirit of the noble traditions of our ancestors. The necessity of raising the effectiveness of spiritual and educational reforms requires a qualitatively new level of work in this area. "We are implementing strict reforms, following the traditions of wisdom of our ancestors and deep understanding of their ideas, a new image of our country we are on the path to forming"12.

The main event of the past 2007 was the decision one of the institutions of the Organization of Islamic Cooperation (OIC) The Islamic World Educational, Scientific and Cultural Organization named Tashkent as the world capital of Islamic culture. This decision was made by ICESCO ${ }^{13}$ in recognition of the capital of Uzbekistan as a city of interethnic and interreligious tolerance, which made a huge contribution not only to the development of Islam, but also to human civilization.

The determination of Tashkent as the capital of Islamic culture is a fair recognition by the international community of the enormous significance of the rich historical heritage of all of Uzbekistan in the scale of world civilization. The efforts that the leadership of the country is taking not only to revive cultural monuments, but also to deeply study the works of great ancestors, restore evidence of various eras, which, as the head of our state has repeatedly emphasized, help to realize one's destiny in life and determine the prospects for progressive development of society.

\footnotetext{
11 Article 18 of The Universal Declaration of Human Rights

12 Ўзбекистон Республикаси Президенти Ш.Мирзиёевнинг Бирлашган Миллатлар Ташкилоти Бош
}

In addition, Bukhara January 1, 2020, received the title of Capital of Islamic Culture. The Islamic Countries Educational, Scientific and Cultural Organization (ICESCO) annually declare 3 cities in Muslim countries as the capitals of Islamic culture. There are in Arab countries, Asia, and a third in Muslim countries in Africa. The organization was approved by the IX Islamic Conference of Ministers of Culture in 2020 as the capitals of Islamic culture in Bukhara, Cairo (Egypt) and Bamako (Mali).

A number of factors related to Bukhara have been taken into account for such a historical and joyful event. In particular, Bukhara is the cradle of the spiritual progress of mankind on Earth; the past is connected with several thousand years of history, witnesses all stages of human development and embodies the processes of modern civilization, as well as the distant past.

Research on the history of cooperation of the Republic of Uzbekistan with the ICESCO was carried out and the following conclusions were drawn from the scientific, practical significance and relevance of the issue:

- Dynamics of socio-political, tradeeconomic and cultural cooperation of the Republic of Uzbekistan with international organizations is provided;

- Uzbekistan's relationship with ICESCO and its humanitarian dimension, in particular in science, education, culture and trends.

- During the years of independence Uzbekistan has achieved tremendous success in preserving national traditions and customs, perpetuating the memory of great ancestors, and improving the sacred burial places.

- The concept of international organizations, the status of their organizations,

Ассамблеясининг 72-сессиясида сўзлаган нутқи. // http://www.press-service.uz/uz/lists/view/

13 ICESCO- Islamic World Educational, Scientific and Cultural Organization 
and the brief description of the establishment of such organizations with Uzbekistan;

- A brief overview of Uzbekistan's cooperation with international organizations;

- Uzbekistan- ICESCO relationships development process analysis;

- Study of cooperation between various organizations of Uzbekistan and the ICESCO;

- formulate a summary on the basis of case studies;

- The Council unanimously adopted the "Tashkent Declaration" which addressed.

\section{Conclusion}

In conclusion, it is safe to say that in today's complex, tense world of religious intolerance, Uzbekistan is one of the few islands of religious tolerance, civic peace and harmony, which not only Uzbeks are convinced, but also numerous guests visiting our country. Highly appreciating the enormous attention paid by the Leadership of the Republic of Uzbekistan to preservation and enhancement of historical scientific and cultural-spiritual heritage, as well as the true values of Islam, such as aspiration for peaceful and tranquil life, tolerance in interethnic and interreligious relations, sense of mutual respect and accord, as well as development and improvement of education system, upbringing of the younger generation in the spirit of mastering the universal and Islamic values and peaks of modern science. Uzbekistan is proud of its unique culture, which has been forming for thousands of years. An opportunity is provided for highlighting the huge role of Uzbekistan in development of Islamic culture, acquaintance with ancient history and cultural heritage, expanding Uzbekistan's cooperation within the framework of ICESCO. Highly appreciating the enormous attention paid by the Leadership of the Republic of Uzbekistan to preservation and enhancement of historical scientific and cultural-spiritual heritage in the spirit of mastering the universal and Islamic values and peaks of modern science.

\section{References:}

1. Ўзбекистон Республикаси Конституцияси [The Constitution of the Republic of Uzbekistan]. Тошкент: Ўқитувчи, 2017. - 17 б.

2. Ўзбекистон Республикаси Олий Мажлисининг Ахборотномаси [Bulletin of the Oliy Majlis of the Republic of Uzbekistan]. Тошкент, 1998 йил, 5-6сонга илова.

3. Выступление Президента Республики Узбекистан Шавката Мирзиёева на Международной конференции «Центральная Азия: одно прошлое и общее будущее, сотрудничество ради устойчивого развития и взаимного процветания» в Самарканде // Народное слово. 11 ноября 2017 г. [Speech by the President of the Republic of Uzbekistan Shavkat Mirziyoyev at the International Conference "Central Asia: One Past and Common Future, Cooperation for Sustainable Development and Mutual Prosperity" in Samarkand // People's Word. November 11, 2017]

4. The Tashkent Declaration of the 43rd session of the council of foreign ministers of the organization of Islamic cooperation «education and enlightenment - path to peace and creativity». Tashkent, 2017.

5. Ўзбекистон Республикаси қонун хужжатлари тўплами [Collection of the legislation of the Republic of Uzbekistan]. - 2017. №6. 70-модда. Тошкент. Б. 25150. 11

6. http://uza.uz/en/politics/president-shavkatmirziyoyev-addressed-the-72nd-sessionof-t-20-09-2017

7. http://www.lex.uz/ru/docs/3107042

8. Рахимов М. Современная история взаимоотношений Узбекистана и стран Центральной Азии с ведущими государствами мира [Modern history of relations between Uzbekistan and the countries of Central Asia with the leading 
states of the world]. Ташкент: Адабиёт учқунлари, 2016. 223 с.

9. https://www.icesco.org/en/2020/02/18/ices co-delegation-examines-in-uzbekistanpreparations-for-bukhara-celebration-asislamic-culture-capital/

10. 10. إبر از -صورة-_الإسلام
11. كتاب_حقوق_الإنسان-في_التعاليم_الإسلامية

12. الإيسيسكوو مستقبل العالم الإسلامي في آفاقه التربوية و العلمية و الثقافية

13. Guide to ICESCO-2016

14. Guide to ICESCO-2017

15. Guide to ICESCO-2018 